\title{
Analisis Penerimaan Pengguna Aplikasi Cerdas Layanan Perizinan Terpadu Untuk Publik (Sicantik) Pada Dinas Penanaman Modal Dan Pelayanan Perizinan Terpadu Satu Pintu (Dpmpptsp) Menggunakan Pendekatan Utaut
}

\author{
Putu Felika Darmawan ${ }^{1}$, I Made Ardwi pradnyana², Gede Hendra Divayana ${ }^{3}$ \\ Program Studi Pendidikan Teknik Informatika \\ Jurusan Teknik Informatika \\ Fakultas Teknik dan Kejuruan \\ Universitas Pendidikan Ganesha \\ Email : edyb4n4t@gmail.com ${ }^{1}$, ardwi.pradnyana@undiksha.ac.id ${ }^{2}$, hendra.divayana@undiksha.ac.id ${ }^{3}$
}

\begin{abstract}
Abstrak - Penelitian ini bertujuan untuk mengetahui seberapa besar hubungan kausal antara penggunaan layanan SiCantik (use behavioral) dengan Performance Expectancy(PE), Effort Expectancy (EE), Social Influence (SI), dan Facilitating Condition (FC) yang dimoderasi oleh variabel moderator Gender (jenis kelamin) dan Age (usia).

Jenis penelitian ini adalah penelitian kausal atau sebab akibat dengan menggunakan pendekatan model UTAUT. Populasi dari penelitian ini adalah masyarakat di kabupaten Buleleng dan untuk sampelnya diambil dari data masyarakat kota Buleleng yang telak melakukan proses permohonan izin di Dinas Penanaman Modal dan Pelayanan Perizinan Terpadu Satu Pintu (DPMPPTSP) dengan jumlah sampel sebanyak 30 sampel/responden. Metode pengumpulan data yang digunakan adalah lembar angket, dan metode pengolahan data yang dignakan adalah metode Partial Least Squares (PLS) dengan pengolahannya menggunakan aplikasi smartPLS.
\end{abstract}

Kata Kunci : SiCantik, smartPLS, PLS, UTAUT, use behavioral.

Abstract - This study aims to determine how much the causal relationship between the use of SiCantik services (use behavioral) and Performance Expectancy (PE), Effort Expectancy (EE), Social Influence (SI), and Facilitating Condition (FC) moderated by Gender moderator variables (gender) and Age (age).

This type of research is causal or causal research using the UTAUT model approach. The population of this study is the people in Buleleng regency and for the sample taken from the data of the Buleleng city community who have done the process of applying for permits in the Investment and Integrated One-Stop Licensing Service (DPMPPTSP) with a sample of 30 samples / respondents. The data collection method used is the questionnaire sheet, and the data processing method used is the Partial Least Squares (PLS) method with processing using smartPLS applications.

Keywords: SiCantik, smartPLS, PLS, UTAUT, use behavioral.

\section{PENDAHULUAN}

Dalam era globalisasi ini, hampir seluruh pihak (swasta maupun pemerintah) memanfaatkan teknologi untuk mengoptimalkan pelayanan mereka. Seiring dengan berjalannya waktu teknologi yang digunakanpun semakin berkembang. Bukan saja tekonologi yang menjadi lebih berkembang, namun masyarakat selaku pengguna dan informasi yang dihasilkan oleh teknologi juga dituntut untuk berkembang maka dari itu pemerintah sebagai salah satu sumber informasi haruslah menyedikan informasi yang terkini.

Dalam sektor Pemerintahan semakin luasnya penggunaan serta kebutuhan SI untuk mendukung kinerja operasionalnya, maka salah satu upaya Pemerintah dalam mengembangkan SI yaitu dikembangkannya sistem informasi terpadu untuk memaksimalkan pelayanan kepada masyarakat secara online. Pada pemerintahan kabupaten Buleleng tepatnya di Dinas Penanaman Modal dan Pelayanan Perizinan Terpadu Satu Pintu (DPMPPTSP) diterapkannya suatu sistem yang dinamakan SiCantik atau Aplikasi Cerdas Layanan Perizinan Terpadu untuk Publik, aplikasi tersebut diperuntukan kepada masyarakat buleleng agar lebih mudah dalam mengurus perizinan karena bersifat online. Permasalahan yang terjadi pada masyarakat buleleng adalah minimnya minat penggunaan layanan pengajuan izin secara online, masyarakat buleleng lebih cenderung menggunakan cara yang konvensional untuk pengajuan perizinan yaitu dengan datang langsung ke kantor dinas perizinan untuk pengajuan perizinan.Penelitian ini mencoba mengungkapkan faktor yang mempengaruhi penggunaan layanan SiCantik pada masyarakat Kabupaten Buleleng. Untuk mengungkapkan faktor-faktor ini peneliti menggunakan model yang diperkenalkan oleh Venkatesh et al. pada tahun 2003. Model ini dinamakan Unified Theory of Acceptance and Use of Technology (UTAUT). Model UTAUT merupakan hasil sintesis berberapa teori perilaku penerimaan, motivasi dan penggunaan teknologi. Ada delapan teori yang digunakan pada UTAUT yaitu: Theory of Reasoned Action (TRA), Technology Acceptance Model (TAM), Motivational Model (MM), Theory of Planned Behavior (TPB), kombinasi TAM dan TPB, Model of PC Utilization (MPTU), Innovation Diffusion Theory (IDT), dan Social Cognitive Theory (SCT). Konsep dari UTAUT dapat dilihat pada table dibawah : 
Table 1. Konsep Model UTAUT

\begin{tabular}{|l|l|l|}
\hline Konsep UTAUT & Akar Konsepsi & Model Sumber \\
\hline \multirow{5}{*}{$\begin{array}{l}\text { Performance } \\
\text { Expectancy }\end{array}$} & $\begin{array}{l}\text { Perceived } \\
\text { Usefulness }\end{array}$ & TAM \\
\cline { 2 - 3 } & $\begin{array}{l}\text { Extrinsic } \\
\text { Motivation }\end{array}$ & MM \\
\cline { 2 - 3 } & Job Fit & MPCU \\
\cline { 2 - 3 } Eealtive Advantage & IDC \\
\cline { 2 - 3 } & $\begin{array}{l}\text { Outcome } \\
\text { Expectations }\end{array}$ & SCT \\
\hline \multirow{5}{*}{ Social Influence } & $\begin{array}{l}\text { Perceived Ease of } \\
\text { Use }\end{array}$ & TAM \\
\cline { 2 - 3 } & Complexity & MPCU \\
\cline { 2 - 3 } Facilitating & Ease of Use & IDT \\
\hline Conditions & Subjective Norm & $\begin{array}{l}\text { TRA,TPB, C- } \\
\text { TAM-TPB }\end{array}$ \\
\cline { 2 - 3 } & Social Factors & MPCU \\
\cline { 2 - 3 } & Image & IDT \\
\hline & $\begin{array}{l}\text { Perceived Behavior } \\
\text { Control }\end{array}$ & $\begin{array}{l}\text { TPB,C-TAM- } \\
\text { TPB }\end{array}$ \\
\cline { 2 - 3 } & $\begin{array}{l}\text { Facilitating } \\
\text { Conditions }\end{array}$ & MPCU \\
\cline { 2 - 3 } & Compatibility & IDT \\
\hline
\end{tabular}

Unified Theory of Acceptance Use of Technology (UTAUT) adalah model teori yang terbentuk dari komnbinasi model-model teori sebelumnya seperti TRA, TAM,TPB, motivational model, Model pemanfaatan personal computer, teori difusi inovasi, dan SCT. Model ini terdiri dari 4 variabel sebagai determinan (faktor penentu) terhadap tujuan dan penggunaan teknologi informasi yaitu ekspektasi kinerja, ekspektasi usaha, pengaruh social, dan kondisi pendukung, serta 4 variabel sebagai moderator(factor penunjang) antara determinan (factor penentu) dengan tujuan dan penggunaan teknologi informasi, yaitu jenis kelamin, usia, pengalaman, dan kesukarelaan. UTAUT menjelaskan bagaimana pengaruh perbedaan individu dalam menggunakan teknologi. Lebih khusus lagi mengenai hubungan antara persepsi kemanfaatan, kemudahan penggunaan, dan niat penggunaan dapat dimoderatori oleh usia, jenis kelamin, dan pengalaman. Sebagai contoh, kekuatan antara manfaat yang dirasakan dan niat penggunaan yang dipengaruhi oleh usia dan gender, hal tersebut lebih signifikan bagi pekerja laki-laki dan muda. Pengaruh persepsi kemudahan penggunaan terhadap niat juga dimoderasi oleh jenis kelamin dan usia sedemikian rupa sehingga lebih signifikan bagi perempuan dan pekerja yang lebih tua, dan mereka mengurangi efek dengan pengalaman.

UTAUT memberikan hipotesis atas variabel-variabelnya yaitu ekspektasi kinerja, ekspektasi usaha dan pengaruh sosial memiliki pengaruh terhadap niat menggunakan sedangkan niat menggunakan dan kondisi pendukung memiliki pengaruh terhadap perilaku penggunaan sistem. UTAUT juga menghipotesiskan variabel-variabel ini di moderasi oleh gender, age, experience, dan voluntarines of Use. Dalam penelitian ini variabel moderasi yang digunakan adalah variabel jenis kelamin dan usia [1].
Venkatesh et al. (2003) memberikan definisi atas variabelvariabelnya yaitu sebagai berikut: ekspektasi kinerja didefinisikan sebagai tingkat kepercayaan seseorang atas kinerjanya yang meningkat merupakan hasil dari penggunaan sistem. Ekspektasi usaha didefinisikan sebagai tingkat kepercayaan seseorang atas sistem yang mudah digunakan maka sistem tersebut dapat menghemat usaha yang dikeluarkan dalam menyelesaikan pekerjaannya. Pengaruh sosial didefinisikan sebagai tingkat kepercayaan seseorang atas orang lain yang meyakinkan dirinya untuk menggunakan sistem. Kondisi pendukung didefinisikan sebagai tingkat kepercayaan seseorang bahwa kondisi yang ada di organisasi baik peran organisasi dan instruktur pembantu memang disediakan untuk mendukung penggunaan sistem. Niat menggunakan didefinisikan sebagai tingkat kehendak seseorang atas penggunaan sistem secara berkelanjutan dengan catatan orang tersebut mendapatkan kesempatan menggunakan sistem. Penggunaan sistem didefinisikan sebagai tingkat penggunaan seseorang atas sistem secara terus menerus karena sistem tersebut memberikan kontribusi positif dalam pekerjaannya [1].

Berdasarkan latar belakang masalah diatas, maka rumusan masala pada penelitian ini adalah sebagai berikut. (1) Seberapa besar hubungan kausal antara penggunaan layanan SiCantik dengan Performance Expectancy (PE). (2) Apakah faktor jenis kelamin (gender) memiliki efek moderasi yang mempengaruhi hubungan faktor Performance Expectancy (PE) terhadap penggunaan layanan SiCantik. (3)Apakah faktor umur (age) memiliki efek moderasi yang mempengaruhi hubungan faktor Performance Expectancy (PE) terhadap penggunaan layanan SiCantik. (4) Seberapa besar hubungan kausal antara penggunaan layanan SiCantik dengan Effort Expectancy (EE). (5) Apakah faktor jenis kelamin (gender) memiliki efek moderasi yang mempengaruhi hubungan faktor Effort Expectancy (EE) terhadap penggunaan layanan SiCantik. (6)Apakah faktor umur (age) memiliki efek moderasi yang mempengaruhi hubungan faktor Effort Expectancy (EE) terhadap penggunaan layanan SiCantik. (7) Seberapa besar hubungan kausal antara penggunaan layanan SiCantik dengan Social Influence (SI). (8) Apakah faktor jenis kelamin (gender) memiliki efek moderasi yang mempengaruhi hubungan faktor Social Influence (SI) terhadap penggunaan layanan SiCantik. (9) Apakah faktor umur (age) memiliki efek moderasi yang mempengaruhi hubungan faktor Social Influence (SI) terhadap penggunaan layanan SiCantik. (10) Seberapa besar hubungan kausal antara penggunaan layanan SiCantik dengan Facilitating Condition (FC). (11) Apakah faktor umur (age) memiliki efek moderasi yang mempengaruhi hubungan faktor Facilitating Condition (FC) terhadap penggunaan layanan SiCantik. 


\section{KAJIAN PUSTAKA}

\section{A. Penelitian Terkait}

Berdasarkan hasil penelitian yang berjudul "Penerapan Model The Unified Theory Of Acceptance And Use Of Technology (UTAUT) Untuk Memahami Tingkat Penerimaan Dan Penggunaan E-Learning (Be Smart) Di Fakultas Teknik Universitas Negeri Yogyakarta" yang dilakukan oleh [2],didapatkan hasil bahwa (1) Konstruk Performance expectancy (PE) berpengaruh positif terhadap konstruk Behavior Intention to Use The System (BIUS) sebesar 29\%. (2) Konstruk Effort Expectancy (EE) berpengaruh positif terhadap konstruk Behavior Intention to Use The System (BIUS) sebesar 23\%. (3) Konstruk Social Influence (SI) berpengaruh positif terhadap konstruk Behavior Intention to Use The System (BIUS) sebesar 27\%. (4) Konstruk Facilitating Condition (FC) berpengaruh positif terhadap konstruk Behavior Intention to Use The System (BIUS) sebesar 30\%. Selain itu koefisien variabel latent Facilitating Condition (FC) terhadap konstruk Behavior Intention to Use The System (BIUS) pada model ini memiliki nilai paling besar diantara nilai koefisien variabel latent pada model hubungan antar konstruk lainnya. Hal yang diadopsi peneliti pada penelitian tersebut menggunakan pendekatan PLS yang bertujuan untuk melakukan prediksi apakah ada hubungan antara konstruk-konstruk (variabel) yang digunakan pada penelitian.

Pada penelitian selanjutnya yang berjudul "Pengaruh Teknologi Adopsi Koran Digital (E-Paper) Terhadap Perilaku Penggunaan Dengan Pendekatan UTAUT (Studi pada Harian Umum Pikiran Rakyat)", yang dilakukan oleh [3] didapatkan analisis deskriptif terhadap variabel Ekspektasi Kinerja, Ekspektasi Usaha, Pengaruh Sosial, Kondisi yang memfasilitasi, dan Kualitas Website seperti berikut. (1) Ekspektasi Kinerja memiliki pengaruh signifikan terhadap penggunaan E-paper. (2) Ekspektasi Usaha memiliki pengaruh signifikan terhadap penggunaan E-paper. (3) Pengaruh Sosial tidak memiliki pengaruh signifikan terhadap penggunaan $E$ paper. (4) Kondisi yang memfasilitasi memiliki pengaruh signifikan terhadap penggunaan E-Paper. (5) Kualitaas website Memiliki Pengaruh Signifikan terhadap penggunaan E-Paper. Hal yang diadopsi peneliti pada penelitian tersebut teknik sampling yang digunakan adalah non probabilitas sampling dimana non probabilitas sampling adalah teknik pengambilan sampel yang tidak memberi peluang/kesempatan sama bagi setiap unsur atau anggota populasi untuk dipilih menjadi sampel dan penjabaran dari hasil perhitungan sampel yang didapat sangat jelas.

Dan pada penelitian yang berjudul "Implikasi Model UTAUT Dalam Menjelaskanfaktor Niat Dan Penggunaan Sipkd Kabupaten Tabanan” yang dilakukan oleh [1] hasil penelitian adalah ekspektasi kinerja dan pengaruh sosial berpengaruh pada niat menggunakan serta niat menggunakan dan kondisi pendukung berpengaruh pada penggunaan SI. Sedangkan ekspektasi usaha tidak berpengaruh pada niat menggunakan. Hasil penelitian ini menunjukan bahwa operator SIPKD belum merasa mudah dalam pengoperasian SIPKD dan sistem ini masih dirasa sulit untuk digunakan. Hal yang diadopsi peneliti pada penelitian tersebut menggunakan 4 skala Likert hal tersebut dilakukan karena peneliti menghindari bias atas jawaban ragu-ragu yang akan dijawab responden.

\section{B. Landasan Teori}

A. Unified Theory of Acceptance and Use of Technology (UTAUT)

Venkatesh, Morris, Davis dan Davis (2003) mengembangkan Unified Theory of Acceptance and Use of Technology (UTAUT) sebagai pengembangan integratif adopsi TI. UTAUT merupakan model formulasi gabungan konstrukkonstruk utama dalam teori dan model penerimaan teknologi diatas. Venkatesh et al. (2003) menjelaskan bahwa utaut terdiri atas tiga konstruk yeng mejadi determinan utama niat penggunaan TI. Tiga konstruk tersebut adalah performance expentancy, effort expectancy, dan social influence. Performan expectancy didefinisikan sebagai "tingkat ekspektasi pengguna bahwa penggunaan sistem akan membantu mencapai kinerja". Konstruk ini memiliki lima konstruk akar, yaitu: PU (dari TAM/TAM2 dekomposisi TPB), motivasi ekstrinsik dari model motivasional, keunggulan relative dari IDT, dan ekspektasi luaran (dari SCT). Effort Expectancy didefinisikan sebagai "tingkat kemudahan yang berhubungan dengan penggunaan sistem". Pengaruh social didefinisikan sebagai "persepsi keyakinan individu bahwa orang lain menilai penting keterlibatannya dalam penggunaan suatu sistem". Venkatesh et al. (2003) juga menemukan bahwa pengaruh kondisi pemfasilitasan dalam penggunaan dimoderasi organisasi dan infrastruktur tersedia untuk mendukung penggunaan sistem" [4].

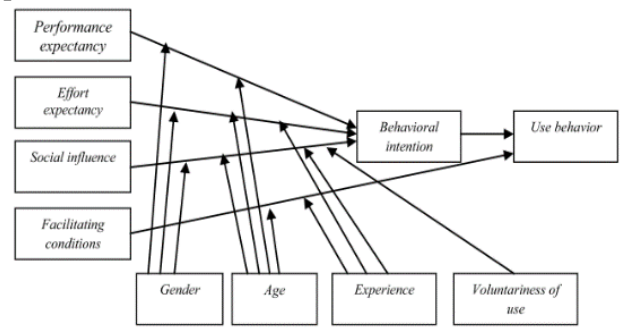

Gambar 1. Model Unified Theory of Acceptance and Use of Technology

B. Partial Least Squares (PLS)

Partial Least Squares (PLS) adalah teknik statistika multivarian yang melakukan perbandingan antara variable dependen berganda dan variable independen jamak. PLS adalah salah satu metode statstika SEM berbasis varian 
yang di desain untuk menyelesaikan regresi berganda ketika terjadi permasalahan spesifik pada data, seperti ukuran sampel penelitian sampel kecil, adanya data yang hilang (missing values) dan multikolinearitas, sebaliknya, regresi Ordinary Least Square (OLS) menghasilkan data yang tidak stabil dan multikolinearitas antara predictor meningkatkan standar error dari koefisien yang diestimasi (field, 2000). Multikolinearitas yang tinggi meningkatkan resiko secara teoritis penolaka hipotesis dalam pengujian regresi [4].

Partial Least Square (PLS) yang sering disebut dengan istilah variancebased SEM dapat menjadi sebuah alternatif untuk melakukan pengujian terhadap hipotesis penelitian. Ghozali dalam [2] mengatakan bahwa PLS merupakan pendekatan alternative yang bergeser dari pendekatan SEM berbasis kovarian menjadi berbasis varian. PLS merupakan teknik analisis yang powerfull karena PLS tidak menggunakan banyak asumsi, bagus untuk ukuran sampel yang kecil maupun besar, dan cocok untuk semua jenis skala data, baik nominal maupun ordinal. Oleh karena itu kelebihan digunakannya PLS dibandingkan dengan pendekatan covariance based SEM adalah asumsi data terdistribusi normal secara multivariat tidak harus terpenuhi. Hal yang membedakan pendekatan PLS dengan covariance based SEM adalah tujuannya. Pendekatan PLS bertujuan untuk melakukan prediksi apakah ada hubungan antara konstruk-konstruk (variabel) yang digunakan pada penelitian, sedangkan covariance based SEM bertujuan untuk mengkonfirmasi suatu teori apakah teori tersebut cocok dengan data hasil observasi yang dilakukan [2].

Dalam [4] dijelaskan pada metode PLS memiliki keunggulan-keunggulan dan kelemahan-kelemahan. Keunggulan-keunggulan PLS adalah sebagai berikut:

1. Mampu memodelkan banyak variable dependen dan variable independen (model komplek).

2. Mampu mengelola masalah multikolinearitas antar variable independen.

3. Hasil tetap kokoh (robust) walaupun terdapat data yang tidak normaldan hilang (missing value).

4. Menghasilkan variable laten independen sacara langsung berbasis cross-product yang melibatkan variabel laten dependen sebagai kekuatan prediksi.

5. Dapat digunakan pada konstruk reflektif dan formatif.

6. Dapat digunakan pada sampel kecil.

7. Tidak mensyaratkan data berdistribusi normal.

8. Dapat digunakan pada data dengan tipe skala berbeda, yaitu: nominal, ordinal, kontinu.

Disamping kelebiha-kelebihannya, PLS memiliki kelemahan-kelemahan antara lain:

1. Sulit menginterpretasi loading variable laten independen jika berdasarkan pada hubungan croosproduct yang tidak ada (seperti pada teknik analisis factor berdasarkan korelasi antar manifest variable independen).

2. Property distribusi estimasi yang tidak diketahui menyebabkan tidak diperolehnya nilai signifikansi kecil melalui prosos bootstrap.

3. Terbatas pada pengujian model estimasi statistika.

C. Aplikasi Cerdas Layanan Perizinan Terpadu untuk Publik (SiCantik)

DPMPTSP melaunching sebuah sistem layanan publik yang dikenal dengan nama Si Cantik (Aplikasi Cerdas Layanan untuk Publik) yang diintegrasikan dengan portal website DPMPTSP pada ahkir Agustus 2017. Layanan Si Cantik berorintasi pada pengoptimalan layanan informasi terkait perijinan untuk masyarakat di wilayah Kabupaten Buleleng. Hasil obsevasi yang telah dilakukan sebelumnya, menunjukkan bahwa terdapat sebanyak 39 ijin yang dilayani di DPMPTSP Kabupaten Buleleng. Izin tersebut terbagi atas 21 perijinan dan 18 non perijinan data bersumber pada DPMPTSP Kab.Buleleng. Pada layanan Si Cantik baru menangani 3 kategori ijin, yaitu Surat Izin Usaha Perdagangan (SIUP), Tanda Daftar Perusahaan (TDP), dan Tanda Daftar Perusahaan (TDUP). Selain memudahkan proses pengajuan, pengadaan layanan ini juga dimaksudkan untuk membantu proses perizinan yang dilakukan oleh seseorang yang berada jauh dari dinas perizinan dengan adanya layanan SiCantik masyarakat dapat dimana saja melakukan proses prizinan tampa datang langsung ke kantor dinas pezinan dan tidak perlu untuk menganttri untuk mlakukan proses perizinan.

Sasaran utama Si Cantik ialah masyarakat yang mengajukan kedua tipe izin tersebut. Sebelum layanan ini dirilis, masyarakat yang berkepentingan harus datang langsung ke dinas untuk melengkapi permohonan izin yang diajukan dan menunggu dalam kurun waktu yang telah ditentukan. Tahap penerimaan ijin yang diproses oleh pihak operator dinas sebelum layanan ini digunakan cukup berbeda. Perbedaannya ditinjau dari cara pengecekan dokumen pengusul yang dilakukan secara manual, kemudian diverifikasi oleh bagian yang berwenang sesuai alur pengajuan ijin yang berlaku. Adanya layanan online ini masyarakat yang berkepentingan dapat dengan mudah mengajukan permohonan izin, dengan mengakses laman https://portalperizinan.bulelengkab.go.id dan melengkapi dokumen sebagai prasyarat untuk memenuhi ijin yang diajukan. Masyarakat yang mengajukan izin tidak perlu lagi menggunakan jasa pihak ketiga dalam mengusulkan izin karena akan dikenakan biaya tambahan yang cukup besar untuk sebuah izin yang diproses. Pengajuan dan pengambilan izin tidak dikenakan biaya apapun/gratis khusus kategori SIUP/TDP. Selanjutnya data pengajuan izin yang sudah terverifikasi akan diproses oleh pihak operator yang tekordinasi antar bagian sehingga meminimalkan miss communication, penginputan data berulang-kali serta terhambatnya izin untuk diproses akibat dokumen yang tercecer. Selanjutnya pengusul akan diberikan 
No. pendaftaran yang dapat dilacak proses pengerjaannya, sehingga pengusul tidak perlu lagi datang ke Dinas hanya untuk memeriksa perkembangan izin yang diajukan.

Dengan adanya SiCantik ini diharapkan dapat dijadikan wadah sebagai tempat untuk memberikan pelayanan public dalam hal pelayanan perizinan kepada masyarakat buleleng. Adapun tampilan SiCantik adalah sebagai berikut:

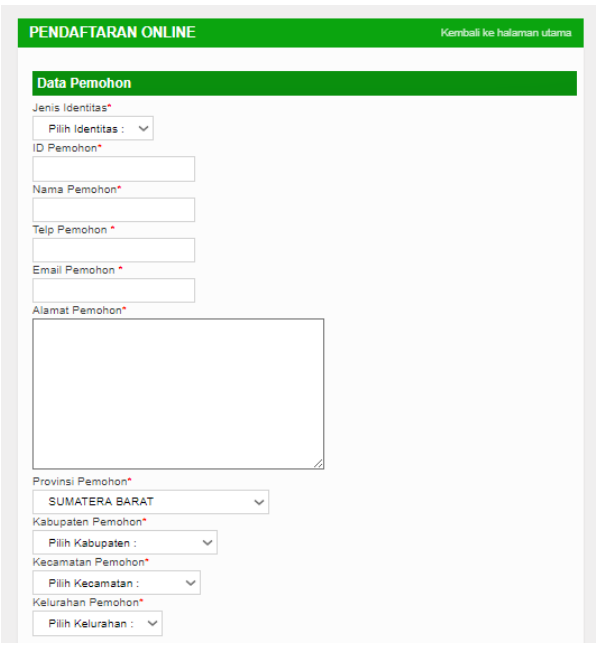

Gambar 2. Form data pemohon

Pada formulir data pemohon, pemohon yang akan membuat surat perizinan mengisi data diri pada setiap kolom, misalnya pada kolom jenis identitas pemohon memilih jenis identitas yang akan menggunakan KTP atau SIM, selanjutnya id pemohon, nama, telpun, dan lain sebagainya.

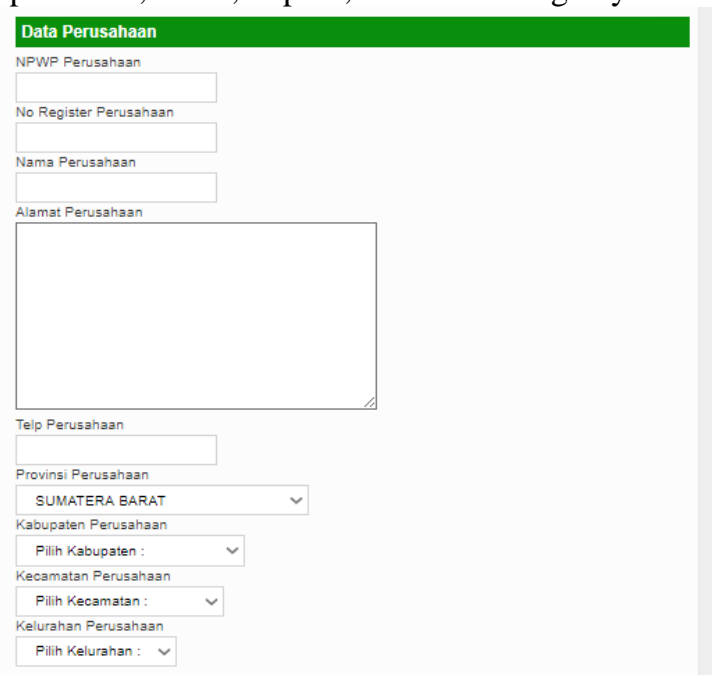

Gambar 3. Form data perusahaan

Pada form data perusahaan, pomohon mengisi form dengan data perusahaan yang akan di buat atau sudah dibuat, misalnya seperti NPWP perusahaan, No register, nama, dan alamat perusahaan,

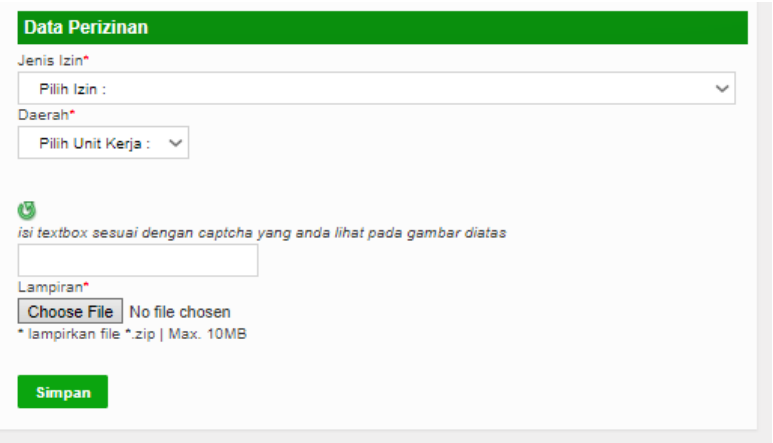

Gambar 4. Form data perizinan

Pada form data perizinan, pemohon memilih perizinan apa yang akan dibuat, pada form tersebut terdapat pilihan jenis izi yang akan diajukan atau akan dibuat dan dearah tempat usaha yang akan di ajukan.

\section{Skala Pengukuran}

Skala pengukuran merupakan kesepakatan yang digunakan sebagai acuanuntuk menentukan panjang pendeknya interval yang ada dalam alat ukur, sehingga alat ukur tersebut bila digunakan dalam pengukuran akan menghasilkan data kuantitatif (Sugiyono, 2010).

Dengan skala likert, maka variabel yang akan diukur dijabarkan menjadi indicator variabel. Kemudian indicator tersebut dijadikan sebagai titik tolak untuk menyusun item-item instrument yang dapat berupa pernyataan atau pertanyaan. Jawaban setiap item instrument yang menggunakan skala likert mempunyai gradasi dari sangat positif samspai sangat negatif, seperti : Sangat Setuju, Setuju, Tidak Setuju, Sangat Tidak Setuju.

\section{E. Kerangka Berfikir}

UTAUT merupakan model formulasi gabungan konstruk-konstruk utama dalam teori dan model penerimaan teknologi. Venkatesh et al. (2003) menjelaskan bahwa UTAUT terdiri atas tiga konstruk yeng mejadi determinan utama niat penggunaan TI. Tiga konstruk tersebut adalah performance expentancy, effort expectancy, dan social influence. Performan expectancy didefinisikan sebagai "tingkat ekspektasi pengguna bahwa penggunaan sistem akan membantu mencapai kinerja". Effort Expectancy didefinisikan sebagai "tingkat kemudahan yang berhubungan dengan penggunaan sistem". social influence didefinisikan sebagai "persepsi keyakinan individu bahwa orang lain menilai penting keterlibatannya dalam penggunaan suatu sistem". pengaruh Facilitating Condition dalam penggunaan dimoderasi organisasi dan infrastruktur tersedia untuk mendukung penggunaan sistem". Secara khusus, model UTAUT disesuaikan berdasarkan kebutuhan dari penelitian. Pertama, sikap dimasukkan sebagai variabel independen yang mempengaruhi perilaku pengguna. Kedua, menghapus variabel moderator experience dan voluntarines of 
use, ketiga penggunaan sebagai variable dependen, dan yang ke empat penggunaan variabel jenis kelamin dan usia sebagai variabel moderator [5].

Berikut digambarkan hubungan antar konstrukkonstruk yang akan diuji :

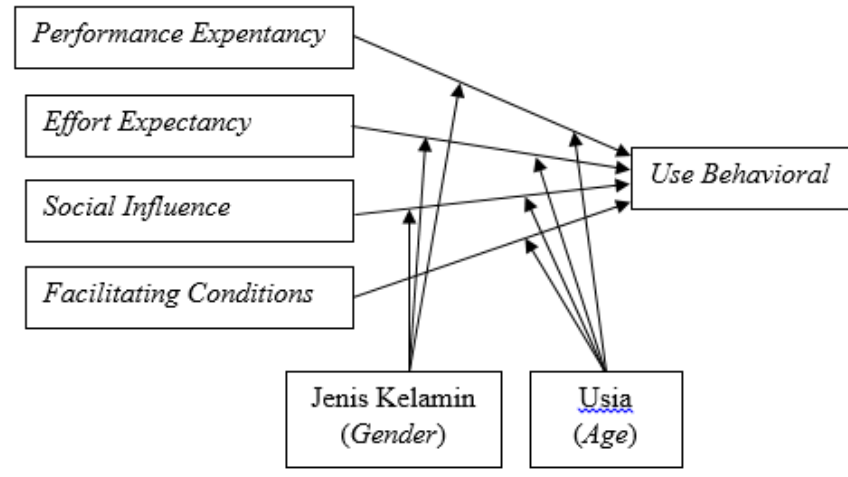

Gambar 5. Model Penelitian

\section{Performance Expectancy (Ekspektasi Kinerja)}

Ekspektasi Kinerja (Performance Expectancy) didefinisikan sebagai seberapa tinggi seseorang percaya bahwa dengan menggunakan sistem akan membantu dia untuk mendapatkan keuntungan- keuntungan kinerja di pekerjaannya. Pada penelitian [6] [7] [8] ekspektasi kinerja berpengaruh positif dan signifikan terhadap perilaku penggunakan (use behavior) dan pada penelitian [9] ekspektasi kinerja tidak berpengaruh positif terhadap perilaku penggunakan (use behavior).

\section{Effort Expectancy (Ekspektasi Usaha)}

Ekspektasi Usaha (Effort Expectancy) didefinisikan sebagai tingkat kemudahan yang dihubungkan dengan penggunaan suatu sistem. Pada penelitian [6] [7] [8] ekspektasi usaha berpengaruh positif dan signifikan terhadap perilaku penggunakan (use behavior) dan pada penelitian [9] ekspektasi usaha tidak berpengaruh positif terhadap perilaku penggunakan (use behavior).

\section{Social Influence (Pengaruh Sosial)}

didefinisikan sebagai sejauh mana seseorang individual mempersiapkan kepentingan yang dipercaya oleh orang-orang lain yang akan mempengaruhinya dalam menggunakan sistem yang baru. pada penelitian [6] [7] pengaruh sosial berpengaruh positif dan signifikan terhadap perilaku penggunakan (use behavior) dan pada penelitian [9] [8] pengaruh sosial tidak berpengaruh positif terhadap perilaku penggunakan (use behavior).

\section{Facilitating Conditions (Kondisi- kondisi pemfasilitasi)}

Kondisi-kondisi pemfasilitasi (Facilitating Conditions) didefinisikan sebagai sejauh mana seseorang percaya bahwa infrastruktur organisasional dan teknikal tersedia untuk mendukung sistem. Pada penelitian [6] [7] Kondisi- kondisi pemfasilitasi berpengaruh positif dan signifikan terhadap perilaku penggunakan (use behavior).

\section{Gender (jenis kelamin)}

Pada variabel moderator Gender (jenis kelamin) dibedakan menjadi dua yaitu laki-laki dan perempuan,pada penelitian [10] menyatakan bahwa variabel moderator Gender (jenis kelamin) tidak memiliki pengaruh pada variabel Performance Expectancy (Ekspektasi Kinerja), Effort Expectancy (Ekspektasi Usaha), Social Influence (Pengaruh Sosial), Facilitating Conditions (Kondisi- kondisi pemfasilitasi), Pada penelitian [11] dinyatakan bahwa variabel moderator Gender (jenis kelamin) memiliki efek moderasi yang signifikan, dan pada penelitian [12] dinyatakan bahwa variabel moderator Gender (jenis kelamin) memiliki pengaruh pada variabel Performance Expectancy (Ekspektasi Kinerja), Social Influence (Pengaruh Sosial), Facilitating Conditions (Kondisikondisi pemfasilitasi).

\section{Age (usia)}

Variabel moderator Age (usia) pada penelitian [10] menyatakan bahwa variabel moderator Age (usia) tidak memiliki pengaruh pada variabel Performance Expectancy (Ekspektasi Kinerja), Effort Expectancy (Ekspektasi Usaha), Social Influence (Pengaruh Sosial), Facilitating Conditions (Kondisi- kondisi pemfasilitasi). Pada penelitian [11] dinyatakan bahwa variabel moderator Age (usia) tidak memiliki efek moderasi yang signifikan, dan pada penelitian [12] dinyatakan bahwa variabel moderator Gender (jenis kelamin) memiliki pengaruh pada variabel Performance Expectancy (Ekspektasi Kinerja), Social Influence (Pengaruh Sosial), Facilitating Conditions (Kondisi- kondisi pemfasilitasi).

\section{F. Hipotesis Penelitian}

Hipotesis adalah pernyataan prektif terhadap hubingan antar variable. Hipotesis menyebut secara khusus bentuk prediksi tentang hubungan antar variable tersebut. Terdapat dua jenis hipotesis, yang pertam hipotesis model merupakan hipotesis yang menjelaskan hubungan structural antar berbagai variabeldalam satu model penelitian. Yang kedua hipotesis parsial berfokus pada pengujian efek prediksi yang menguji signifikansi parsial hubungan antar variable. Kriteria utama yang digunakan untuk mengukur signifikansi tersebut adalah nili t-statistik. Pada penelitian ini peneliti menggunakan jenis hipotesis parsial, maka hipotesis pada penelitian ini adalah :

H1 : Performance Expectancy (PE) berpengaruh positif terhadap penggunaan layanan SiCantik.

$\mathrm{H} 2$ : Effort Expectancy (EE) berpengaruh positif terhadap penggunaan layanan SiCantik.

H3 : Social Influence (SI) berpengaruh positif terhadap penggunaan layanan SiCantik. 
H4 : Facilitating Condition (FC) berpengaruh positif terhadap penggunaan layanan SiCantik.

H5 : Terdapat pengaruh positif dari efek moderasi jenis kelamin (gender) pada faktor Performance Expectancy (PE) terhadap penggunaan layanan SiCantik.

H6 : Terdapat pengaruh positif dari efek moderasi jenis kelamin (gender) pada faktor Effort Expectancy (EE) terhadap penggunaan layanan SiCantik.

H7 : Terdapat pengaruh positif dari efek moderasi jenis kelamin (gender) pada faktor Social Influence (SI) terhadap penggunaan layanan SiCantik.

H8 : Terdapat pengaruh positif dari efek moderasi umur (gender) pada faktor Performance Expectancy (PE) terhadap penggunaan layanan SiCantik.

H9 : Terdapat pengaruh positif dari efek moderasi umur (gender) pada faktor Effort Expectancy (EE) terhadap penggunaan layanan SiCantik.

H10 : Terdapat pengaruh positif dari efek moderasi umur (gender) pada faktor faktor Social Influence (SI) terhadap penggunaan layanan SiCantik.

H11 : Terdapat pengaruh positif dari efek moderasi umur (gender) pada faktor faktor Facilitating Condition (FC) terhadap penggunaan layanan SiCantik.

\section{METODOLOGI PENELITIAN}

Jenis penelitian ini merupakan penelitian survei. Metode survei digunakan untuk mendapatkan data dari tempat tertentu yang alamiah (bukan buatan), tetapi peneliti melakukan perlakuan dalam pengumpulan data dengan mengedarkan kuesioner dan wawancara terhadap narasumber.

\section{A. Variabel Penelitian}

Dalam penelitian ini terdapat variabel dependen dan independen.Variabel dependen (terikat) yaitu variabel perilaku penggunaan (use behavior), Variabel independen (bebas) yang terdiri dari variabel Ekspektasi kinerja (Performance Expectancy), Ekspektasi usaha (Effort Expectancy), Faktor sosial (Social Influence), Kondisi yang memfasilitasi (Facilitating Condition), dan Variabel moderator yang kterdiri dari variabel jenis kelamin (Gender) dan umur (Age).

\section{B. Populasi dan Sampel}

Populasi adalah wilayah generalisasi yang terdiri atas obyek/subyek yang mempunyai kualitas dan karakteristik tertentu yang ditetapkan oleh peneliti untuk dipelajari dan kemudian ditarik kesimpulannya (Sugiyono dalam Silviasasmi, 2017). Berdasarkan pengertian populasi tersebut, populasi dalam penelitian ini adalah pengguna layanan SiCantik di kota Singaraja. Pengambilan sampel dalam penelitian ini menggunakan non probabilitas sampling dimana non probabilitas sampling adalah teknik pengambilan sampel yang tidak memberi peluang/kesempatan sama bagi setiap unsur atau anggota populasi untuk dipilih menjadi sampel. (Ghozali dalam Rivai, 2014) Besarnya sampel pada penelitian yang menggunakan pendekatan PLS yang memiliki porsi (populasi) besar minimal direkomendasikan sebesar 30 sampai dengan 100 kasus atau responden. Melihat dari jumlah populasi yang sangat luas dan keterbatasan waktu untuk itu peneliti akan mengambil sampel sejumlah 30 responden.

\section{Teknik Pengumpulan Data}

Dalama [4] mengatakan Secara umum, pengumpulan data penelitian dapat dapat dibedakan menjadi metode kuesioner, observasi, wawancara, diskusi kelompok terarah, eksperimentasi labolatorium dan lapangan.

Teknik pengumpulan data dalam penelitian ini yaitu :

\section{a. Wawancara}

Wawancara adalah metode pengumpulan data yang banyak digunakan dalam penelitian-penelitian eksploratif dan studi lapangan. Pada prinsipnya, teknik wawancaa tidak berbeda dengan kuesioner dengan format pernyataan/pertanyaan terbuka. Wawancara bertujuan mendapatkan informasi secara langsung kepada nara submber maupun responden. Metode ini tepat digunakn untuk observasi awal dan menggali informasi lebih dalam ketika survey kuesioner tidak menghasilkan cukup informasi.

Wawancara dilakukan dengan terlebih dahulu mempersiapkan pedoman tertulis tentang apa yang hendak ditanyakan kepada responden.

b. Kuesioner

Kuesioner adalah pengumpulan data primer menggunakan sejumlah item-item pertanyaan atau pernyataandengan format tertentu. Kuesioner adalah metode pengupulan data yang paling umum digunakan dalam studi laporan atau survei. Kuesioner memiliki keunggulan karena memuat informasi yang efektif dan efesien sesuai dengan tujuan penelitian.

Kuesioner diberikan kepada responden berupa pernyataan tertulis yang bertujuan untuk menganalisis penerimaan layanan SiCantik.

\section{Jenis dan Sumber Data}

\section{Jenis data penelitian}

a.) Data kualitatif dalam penelitian ini yaitu fakta yang terjadi di lapangan mengenai penerimaan layanan SiCantik yang diperoleh melalui wawancara dengan kepala Dinas Penanaman Modal dan pelayanan Perizinan Terpadu Satu Pintu .

b.) Data Kuantitatif dalam penelitian ini yaitu data yang didapatkan dari hasil penyebaran kuesioner kepada masyarakat kota singaraja. 
2. Sumber data penelitian

a.) Data primer dalam penelitian ini berupa data hasil survei terhadap pengguna layanan SiCacntik.

b.) Data sekunder dalam penelitian ini didapatkan melalui jurnal penelitian terkait, buku dan literatur lainnya yang relevan dengan penelitian.

\section{E. Uji Coba Instrumen Penelitian}

Dalam penelitian ini dilakukan uji validitas untuk menunjukkan tingkat kevalidan atau kesahihan sesuatu instrument, dan uji reliabilitas dilakukan untuk menunjukkan bahwa suatu instrument cukup dapat dipercaya untuk digunakan sebagai alat pengumpul data karena instrumen tersebut sudah baik.

a. Uji Validitas

Validitas yang diuji pada instrumen ini adalah validitas isi, yaitu kesanggupan alat ukur itu untuk mengukur isi yang seharusnya diukur. Hasil penilaian pakar terhadap validasi isi umumnya bersifat kuantitatif. Gregory (2000) mengembangkan suatu teknik pengujian validasi isi yang lebih kuantitatif. Teknik tang dikembangkan Gregory masih menggunakan penilaian pakar, namun hasil penilaian sudah dikuantitatifkan. Adapun mekanisme perhitungan validasi isi [14],

b. Uji Reliabilitas

Tahapan perhitungan uji reliabilitas dengan menggunakan teknik alpha cronbach, ( Siregar dalam Silviasasmi, 2017)

\section{HASIL \& PEMBAHASAN}

\section{HASIL}

Deskripsi data yang disajikan adalah untuk memberikan gambaran mengenai pengambilan data yang dilakukan di lapangan. Pengambilan data dilakukna dengan menyebar atau memberikan kuesioner kepada responden yaitu masyarakat buleleng yang pernah melakukan perizinan sebanyak 30 responden. Penelitian ini dilakukan dengan cara

mendatangi langsung responden.

Data dalam penelitian ini terdiri dari beberapa variabel yaitu ekspektasi kinerja, ekspektasi usaha, faktor sosial, kondisi yang memfasilitasi, dan prilaku pengguna serta dalam penelitian ini peneliti menggunakan variabel moderator yaitu variabel moderator usia dan jenis kelamin.

\section{A. Uji Coba Instrumen}

\section{Hasil uji Gregory}

Penyusunan validitas instrumen dalam penelitian ini dilakukan beberapa kali uji validitas isi dengan melibatkan dua orang penilai penilai 1 sebagai penilai isi dan penilai 2 sebagai penilai bahasa. Uji validitas isi dilakukan dengan menggunakan formula Gregory yang ditabulasi dalam matriks.selanjutnya ditabulasi ke dalam bentuk matriks $2 \times 2$,

$$
\begin{aligned}
& \text { Validasi isi }=\frac{D}{A+B+C+D} \\
& \text { validasi isi }=\frac{32}{0+0+0+32} \\
& \text { validasi isi }=\frac{32}{32}=1,00
\end{aligned}
$$

Jadi koefisien validitas isi instrumen yang diuji coba adalah 1,00 yang berkategori sangat tinggi.

\section{Uji faliditas}

Uji validitas dilakukan untuk mengukur tingkat kevalidan suatu instrument. Pada penelitian ini kuisioner telah diujicobakan ke 20 responden diluar sampel. Item pernyataan dinyatakan valid apabila $r$-hitung $>r$-tabel dengan hasil sebanyak 19 butir pertanyaan dinyatakan valid dan 13 pertanyaan dinyatakan tidak valid.

\section{Uji reliabilitas}

Uji reliabilitas dilakukan untuk menguji derajat konsistensi dan stabilitas instrument dalam interval waktu tertentu. Nilai cronbach alpha pada pengujian reliabilitas ini adalah 0,890 dari 32 butir pernyataan yang diuji cobakan kepada 20 responden pengguna yaitu masyarakat singaraja.

Berdasarkan kriteria tinggi rendahnya nilai koefisien reliabilitas, nilai crocnbach alpha pada instrumen ini berkategori sangat tinggi yaitu $0,80 \leq 0,890<1$. Setelah instrumen selesai diujicobakan, selanjutnya instrumen disebar ke sampel responden yang berjumlah 30 responden.

\section{Karakteristik Responden}

Karakteristik responden dalam penelitian ini yakni mengenai jenis kelamin, dan umur. Peneliti memperoleh data karakteristik beradasarkan pertanyaan pada kuisioner dibagian demografi responden, adapun hasil karakteriktik responden dalam penelitian ini adalah sebagai berikut : 


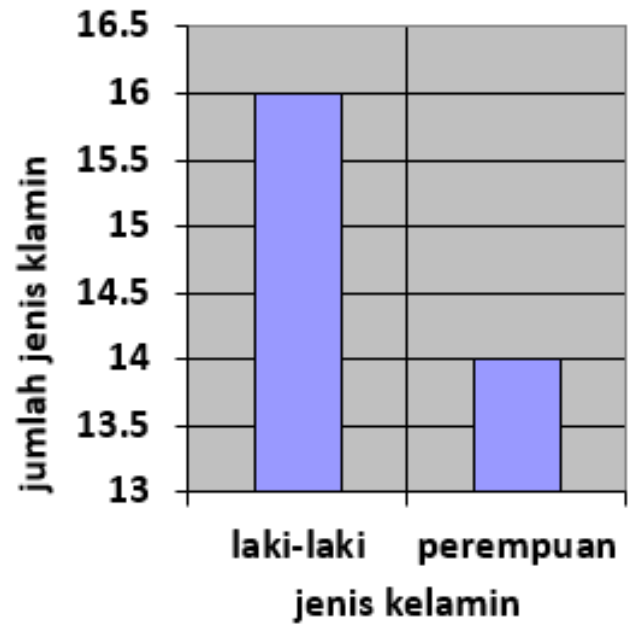

Gambar 4.6 Grafik Jenis Kelamin

Pada gambar diatas menunjukkan bahwa pada penelitian ini terdapat 30 responden yang terdiri dari 16 responden lakilaki dan 14 responden perempuan. Selanjutnya dari data umur responden, diperoleh data seperti gambar di bawah

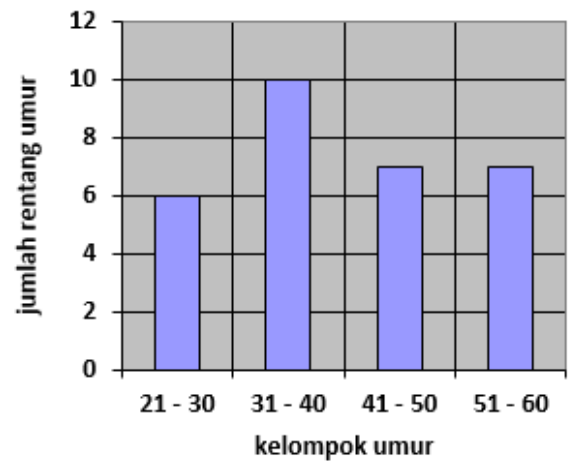

Gambar 4.7 Grafik Umur

bahwa dari 30 responden, 6 responden berada pada rentang umur 21-30 tahun, 10 reponden berada pada rentang umur 31-40 tahun, 7 responden dengan rentang umur 41-50 tahun dan 7 responden dengan rentang umur 51-60 tahun.

\section{Analisis Model Pengukuran (Outher Model)}

Analisis model pengukuran dilakukan melalui empat tahapan pengujian, yaitu individual item reliability, internal concistency reliability, average variance extracted, dan discriminant validity. Ketiga pengujian pertama dikelompokkan menjadi convergent validity yang mengukur besarnya korelasi antara indikator dengan variabel laten.

\section{a. Uji Individual Item Reliability}

Pengujian ini dilakukan dengan melihat nilai dari standardized loading factor. Nilai loading factor menggambarkan besarnya korelasi antar setiap item pengukuran indikator dengan variabel lainnya. Nilai yang ideal untuk menyatakan suatu indicator itu valid adalah diatas 0,7. Jika hal ini tidak dipenuhi, indikator yang nilai loadingnya kurang dari 0,7 harus dihapus dari diagram jalur yang diusulkan karena indicator tersebut nilai reliabilitas dan validitasnya jelek (Santosa, 2018).

Tabel 4.1 Hasil Uji Loading Faktor dengan SmartPLS

\begin{tabular}{|l|l|l|l|l|l|}
\hline Indicator & $\begin{array}{l}\text { Ekspektasi } \\
\text { kinerja }\end{array}$ & $\begin{array}{l}\text { Ekspektasi } \\
\text { usaha }\end{array}$ & $\begin{array}{l}\text { Factor } \\
\text { sosial }\end{array}$ & $\begin{array}{l}\text { Kondisi Yang } \\
\text { Memfasilitasi }\end{array}$ & $\begin{array}{l}\text { Prilaku } \\
\text { pengguna }\end{array}$ \\
\hline EK1 & 0.830 & & & & \\
\hline EK2 & 0.866 & & & & \\
\hline EK4 & 0.864 & & & & \\
\hline EK5 & 0.850 & & & & \\
\hline EK6 & 0.875 & & & & \\
\hline EU9 & & 0.739 & & & \\
\hline EU10 & & 0.864 & & & \\
\hline EU11 & & 0.820 & & & \\
\hline EU12 & & 0.727 & & & \\
\hline
\end{tabular}

\begin{tabular}{|l|l|l|l|l|l|}
\hline Indicator & $\begin{array}{l}\text { Ekspektasi } \\
\text { kinerja }\end{array}$ & $\begin{array}{l}\text { Ekspektasi } \\
\text { usaha }\end{array}$ & $\begin{array}{l}\text { Factor } \\
\text { sosial }\end{array}$ & $\begin{array}{l}\text { Kondisi Yang } \\
\text { Memfasilitasi }\end{array}$ & $\begin{array}{l}\text { Prilaku } \\
\text { pengguna }\end{array}$ \\
\hline FS13 & & & 0.746 & & \\
\hline FS14 & & & 0.896 & & \\
\hline FS15 & & & 0.926 & & \\
\hline FS16 & & & 0.774 & & \\
\hline KM17 & & & & 0.858 & \\
\hline KM18 & & & & 0.803 & \\
\hline KM19 & & & & 0.793 & \\
\hline
\end{tabular}

Pada uji loading factor peneliti juga memberikan hasil dari interkasi antara variabel bebas dengan variabel moderator. Interaksi pertama antara variabel Ekspektasi Kinerja dengan variabel moderator jenis kelamin dan umur.

Table 4.2 Hasil Uji Loading Faktor Interaksi Variabel Moderator dengan Ekspektasi Kinerja 


\begin{tabular}{|l|l|}
\hline INDIKATOR & HASIL LOADING FAKTOR \\
\hline Ekspektasi Kinerja * Jenis Kelamin & 0.986 \\
\hline Ekspektasi Kinerja * umur & 0.954 \\
\hline
\end{tabular}

Table 4.3 Hasil Uji Loading Faktor Interaksi Variabel Moderator dengan Ekspektasi Usaha

\begin{tabular}{|l|l|}
\hline INDIKATOR & HASIL LOADING FAKTOR \\
\hline Ekspektasi Usaha * Jenis Kelamin & 0.992 \\
\hline Ekspektasi Usaha * umur & 0.972 \\
\hline
\end{tabular}

Table 4.4 Hasil Uji Loading Faktor Variabel Moderator dengan Pengaruh Sosial.

\begin{tabular}{|l|l|}
\hline INDIKATOR & HASIL LOADING FAKTOR \\
\hline Faktor Sosial * umur & 0.984 \\
\hline Faktor Sosial * Jenis Kelamin & 0.927 \\
\hline
\end{tabular}

Table 4.5 Hasil Uji Loading Faktor Variabel Moderator dengan Kondisi Yang Memfasilitasi.

\begin{tabular}{|l|l|}
\hline INDIKATOR & HASIL LOADING FAKTOR \\
\hline Kondisi yang memfasilitasi * umur & 1.009 \\
\hline
\end{tabular}

Berdasarkan pengujian item individual reliability diperoleh diagram jalur dengan analisis menggunakan SmartPLS sesuai dengan gambar dibawah

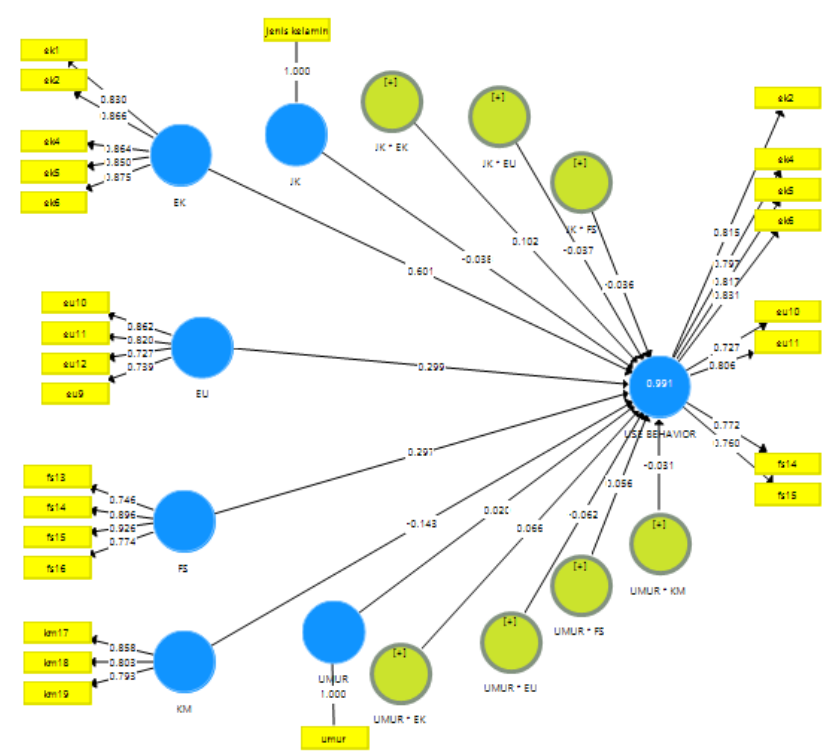

Gambar 4.8 Model Diagram Jalur menggunakan SmartPLS
Table 46Hasil Uji Internal Consistency Reliability dan Convergent Validity dengan SmartPLS

\begin{tabular}{|c|c|c|c|}
\hline Variabel & $\begin{array}{l}\text { Cronbach's } \\
\text { Alpha }\end{array}$ & $\begin{array}{l}\text { Composite } \\
\text { Reliability }\end{array}$ & AVE \\
\hline Ekspektasi Kinerja & 0.910 & 0.933 & 0.735 \\
\hline Ekspektasi Usaha & 0.798 & 0.868 & 0.622 \\
\hline Factor Sosial & 0.858 & 0.904 & 0.704 \\
\hline $\begin{array}{l}\text { Kondisi Yang } \\
\text { Memfasilitasi }\end{array}$ & 0.753 & 0.859 & 0.670 \\
\hline $\begin{array}{l}\text { Ekspektasi Kinerja * } \\
\text { jenis kelamin }\end{array}$ & 1.000 & 1.000 & 1.000 \\
\hline $\begin{array}{l}\text { Ekspektasi Kinerja * } \\
\text { Umur }\end{array}$ & 1.000 & 1.000 & 1.000 \\
\hline $\begin{array}{l}\text { Ekspektasi Usaha * } \\
\text { Jenis Kelamin }\end{array}$ & 1.000 & 1.000 & 1.000 \\
\hline $\begin{array}{l}\text { Ekspektasi Usaha * } \\
\text { Umur }\end{array}$ & 1.000 & 1.000 & 1.000 \\
\hline $\begin{array}{l}\text { Faktor Sosial * Jenis } \\
\text { Kelamin }\end{array}$ & 1.000 & 1.000 & 1.000 \\
\hline $\begin{array}{lll}\text { Factor } & \text { Sosial } & * \\
\text { Umur } & & \end{array}$ & 1.000 & 1.000 & 1.000 \\
\hline $\begin{array}{lr}\text { Kondisi } & \text { Yang } \\
\text { Memfasilitasi } & * \\
\text { Umur } & \end{array}$ & 1.000 & 1.000 & 1.000 \\
\hline Jenis kelamin & 1.000 & 1.000 & 1.000 \\
\hline Umur & 1.000 & 1.000 & 1.000 \\
\hline Prilaku pengguna & 0.914 & 0.930 & 0.626 \\
\hline
\end{tabular}




\section{c. Uji Discriminant Validity}

Discriminant Validity diuji pada level indikator. Pada level indikator, tidak ada indikator yang memberikan loading ke peubah laten yang lebih tinggi disbanding peubah laten yang seharusnya. Nama lain yang sering digunakan adalah cross loading. Ukuran cross loading adalah mebandingkan korelasi indikatornya dengan indikator blok lainnya. Jika nilai korelasi lebih tinggi dari korelasi dengan blok lainnya, hal ini menunjukkan indikator tersebut memprediksi ukuran pada blok mereka lebih baik dari blok lainnya.

Table 4.7 Hasil Uji Discriminant Validity dengan SmartPLS

\begin{tabular}{|l|l|l|l|l|l|}
\hline Indicator & $\begin{array}{l}\text { Ekspektasi } \\
\text { kinerja }\end{array}$ & $\begin{array}{l}\text { Ekspektasi } \\
\text { usaha }\end{array}$ & $\begin{array}{l}\text { Factor } \\
\text { sosial }\end{array}$ & $\begin{array}{l}\text { Kondisi Yang } \\
\text { Memfasilitasi }\end{array}$ & $\begin{array}{l}\text { Prilaku } \\
\text { pengguna }\end{array}$ \\
\hline EK1 & 0.830 & 0.750 & 0.647 & 0.490 & 0.842 \\
\hline EK2 & 0.866 & 0.704 & 0.481 & 0.505 & 0.815 \\
\hline EK4 & 0.864 & 0.599 & 0.513 & 0.533 & 0.797 \\
\hline EK5 & 0.850 & 0.650 & 0.564 & 0.491 & 0.817 \\
\hline EK6 & 0.875 & 0.642 & 0.601 & 0.540 & 0.831 \\
\hline EU9 & 0.611 & 0.739 & 0.635 & 0.790 & 0.628 \\
\hline EU10 & 0.603 & 0.862 & 0.577 & 0.655 & 0.727 \\
\hline EU11 & 0.708 & 0.820 & 0.563 & 0.445 & 0.806 \\
\hline EU12 & 0.525 & 0.727 & 0.611 & 0.717 & 0.573 \\
\hline FS13 & 0.458 & 0.602 & 0.746 & 0.627 & 0.562 \\
\hline FS14 & 0.650 & 0.650 & 0.896 & 0.631 & 0.772 \\
\hline FS15 & 0.610 & 0.649 & 0.926 & 0.634 & 0.760 \\
\hline FS16 & 0.450 & 0.622 & 0.774 & 0.788 & 0.569 \\
\hline KM17 & 0.422 & 0.701 & 0.666 & 0.858 & 0.540 \\
\hline KM18 & 0.580 & 0.598 & 0.622 & 0.803 & 0.606 \\
\hline KM19 & 0.463 & 0.677 & 0.638 & 0.793 & 0.566 \\
\hline
\end{tabular}

6. Analisis Model Struktural (Inner Model)

Analisis model struktural dilakukan dalam enam tahapan pengujian yaitu sebagai berikut :

a. Asesmen kolinearitas

Pengujian ini dilakukan dengan melihat nilai VIF.

Table 4.8 Hasil Uji Asesmen Kolinearitas

\begin{tabular}{|l|l|l|l|}
\hline Indicator & VIF & Indicator & VIF \\
\hline EK1 & 2.985 & FS16 & 1.685 \\
\hline EK2 & 3.646 & KM17 & 1.843 \\
\hline EK4 & 2.816 & KM18 & 1.457 \\
\hline EK5 & 2.981 & KM19 & 1.502 \\
\hline EK6 & 3.350 & Ekspektasi Kinerja * jenis kelamin & 1.000 \\
\hline EU9 & 1.684 & Ekspektasi Kinerja * Umur & 1.000 \\
\hline EU10 & 2.478 & Ekspektasi Usaha * Jenis Kelamin & 1.000 \\
\hline EU11 & 2.953 & Ekspektasi Usaha * Umur & 1.000 \\
\hline EU12 & 1.704 & Faktor Sosial * Jenis Kelamin & 1.000 \\
\hline FS13 & 1.656 & Factor Sosial * Umur & 1.000 \\
\hline FS14 & 3.956 & Kondisi Yang Memfasilitasi * Umur & 1.000 \\
\hline FS15 & 4.373 & & \\
\hline & & & \\
\hline
\end{tabular}

Berdasarkan tabel diatas, hasil nilai kolinieritas yang dilihat dari VIF tidak terdapat indikator nilai yang lebih dari 5. b. Koefisien Jalur

Pengujian ini dilakukan dengan melihat nilai ambang batas di atas 0,1 untuk menyatakan bahwa hubungan variabel mempunyai pengaruh didalam model.

Tabel 4.15 Hasil Uji Koefisien Jalur

\begin{tabular}{|l|l|}
\hline Variabel & Prilaku Pengguna \\
\hline Ekspektasi Kinerja & 0.601 \\
\hline Ekspektasi Usaha & 0.299 \\
\hline Factor Sosial & 0.297 \\
\hline Kondisi Yang Memfasilitasi & -0.143 \\
\hline
\end{tabular}

Pada tabel diatas, dari 4 variabel yang mempengaruhi terdapat satu nilai di bawah 0,1 yaitu kondisi yang memfasilitasi sehingaa satu variabel tersebut tidak mempunyai pengaruh dalam model.

\section{c. Koefisien Determinasi}

Ukuran yang digunakan untuk melakukan pengujian dengan koefisien determinasi adalah menggunakan nilai RSquare (R2). Nilai R-square menunjukkan seberapa besar kemampuan variabel bebas menjelaskan terhadap variabel terikat.

Table 4.9 Hasil Nilai R-Square

\begin{tabular}{|l|l|l|}
\hline Variabel & R Square & R Square Adjusted \\
\hline Prilaku pengguna & 0.991 & 0.984 \\
\hline
\end{tabular}

Berdasarkan nilai R-square yang diperoleh sesuai dengan tabel 4.16, hasil analisis variabel prilaku pengguna adalah 0.991 yang berarti bahwa variabel prilaku pengguna dapat dijelaskan sebesar $99.1 \%$ oleh variabel ekspektasi kinerja, ekspektasi usaha, pengaruh social, dan kondisi yang memfasilitasi.

\section{Pengujian Hipotesis}

Pengujian hipotesis digunakan untuk menunjukkan tingkat signifikansi parameter dari variabel indikator. Uji yang digunakan adalah t-statistics atau uji t. Signifikansi parameter dapat dievaluasi melalui prosedur resampling bootstrapping. Tingkat signifikansi $\alpha$ yang digunakan adalah $5 \%$, sehingga nilai t-tabel adalah sebesar 1,96. 
Table 4.10 Hasil Pengujian Hipotesis

\begin{tabular}{|l|l|l|l|}
\hline Indikator & Original Sample & T Statistics & P Value \\
\hline $\begin{array}{l}\text { Ekspektasi Kinerja -> } \\
\text { prilaku pengguna }\end{array}$ & 0.601 & 4.464 & 0.000 \\
\hline $\begin{array}{l}\text { Ekspektasi usaha -> } \\
\text { prilaku pengguna }\end{array}$ & 0.299 & 3.103 & 0.004 \\
\hline $\begin{array}{l}\text { Factor social >> } \\
\text { prilaku pengguna }\end{array}$ & 0.297 & 2.093 & 0.045 \\
\hline $\begin{array}{l}\text { Kondisi yang memfasilitasi -> } \\
\text { prilaku pengguna }\end{array}$ & -0.143 & 1.426 & 0.164 \\
\hline $\begin{array}{l}\text { Jenis kelamin * Ekspektasi } \\
\text { Kinerja -> } \\
\text { prilaku pengguna }\end{array}$ & 0.102 & 0.594 & 0.557 \\
\hline $\begin{array}{l}\text { Jenis kelamin * Ekspektasi } \\
\text { usaha -> } \\
\text { prilaku pengguna }\end{array}$ & -0.0377 & 0.278 & 0.783 \\
\hline $\begin{array}{l}\text { Jenis kelamin * Factor social -> } \\
\text { prilaku pengguna }\end{array}$ & -0.036 & 0.237 & 0.815 \\
\hline $\begin{array}{l}\text { Umur * Ekspektasi Kinerja -> } \\
\text { prilaku pengguna }\end{array}$ & 0.066 & 0.471 & 0.641 \\
\hline $\begin{array}{l}\text { Umur * Ekspektasi usaha -> } \\
\text { prilaku pengguna }\end{array}$ & -0.062 & 0.403 & 0.690 \\
\hline $\begin{array}{l}\text { Umur * Factor social > } \\
\text { prilaku pengguna }\end{array}$ & 0.056 & 0.369 & 0.715 \\
\hline $\begin{array}{l}\text { Umur * Kondisi yang } \\
\text { memfasilitasi > } \\
\text { prilaku pengguna }\end{array}$ & -0.031 & 0.457 & 0.799 \\
\hline
\end{tabular}

Berdasarkan tabel 4.20 hasil pengujian hipotesis yang dilakukan, didapatkan hasil pembahasan sebagai berikut :

1. Hipotesis pertama (H1) yaitu terdapat pengaruh positif antara Ekspektasi Kinerja terhadap prilaku pengguna layanan SiCantik. Hipotesis ini diterima karena nilai tstatistics variabel Ekspektasi Kinerja terhadap variabel prilaku pengguna lebih besar dari nilai t-tabel $(1,96)$ yaitu 4.464 .

2. Hipotesis kedua $(\mathrm{H} 2)$ yaitu terdapat pengaruh positif antara Ekspektasi Usaha terhadap prilaku pengguna layanan SiCantik. Hipotesis ini diterima karena nilai tstatistics variabel Ekspektasi Usaha terhadap variabel prilaku pengguna lebih besar dari nilai t-tabel $(1,96)$ yaitu 3.103 .

3. Hipotesis ketiga (H3) yaitu terdapat pengaruh positif antara factor sosial terhadap prilaku pengguna layanan SiCantik. Hipotesis ini diterima karena nilai t-statistics variabel factor sosial terhadap variabel prilaku pengguna lebih besar dari nilai t-tabel $(1,96)$ yaitu 2.093.

4. Hipotesis keempat $(\mathrm{H} 4)$ yaitu terdapat pengaruh negatif antara kondisi yang memfasilitasi terhadap prilaku pengguna layanan SiCantik. Hipotesis ini ditolak karena nilai t-statistics variabel factor sosial terhadap variabel prilaku pengguna lebih kecil dari nilai t-tabel $(1,96)$ yaitu 1.426 .

5. Hipotesis kelima (H5) yaitu tidak terdapat efek moderasi Jenis Kelamin yang memperkuat hubungan antara Ekspektasi Kinerja terhadap prilaku pengguna layanan SiCantik. Hipotesis ini ditolak karena nilai t-statistics dari variabel moderator Jenis Kelamin pada faktor
Ekspektasi Kinerja terhadap prilaku pengguna layanan SiCantik lebih kecil dari nilai t-tabel $(1,96)$ yaitu 0,594 .

6. Hipotesis keenam (H6) yaitu tidak terdapat efek moderasi Jenis Kelamin yang memperkuat hubungan antara Ekspektasi usaha terhadap prilaku pengguna layanan SiCantik. Hipotesis ini ditolak karena nilai tstatistics dari variabel moderator Jenis Kelamin pada faktor Ekspektasi usaha terhadap prilaku pengguna layanan SiCantik lebih kecil dari nilai t-tabel $(1,96)$ yaitu 0,278 .

7. Hipotesis ketujuh (H7) yaitu tidak terdapat efek moderasi Jenis Kelamin yang memperkuat hubungan antara faktor social terhadap prilaku pengguna layanan SiCantik. Hipotesis ini ditolak karena variabel moderator Jenis Kelamin pada faktor faktor sosial terhadap prilaku pengguna layanan SiCantik lebih kecil dari nilai t-tabel $(1,96)$ yaitu 0,237 .

8. Hipotesis kedelapan (H8) yaitu tidak terdapat efek moderasi umur yang memperkuat hubungan antara Ekspektasi kinerja terhadap prilaku pengguna layanan SiCantik. Hipotesis ini ditolak karena nilai t-statistics dari variabel moderator umur pada faktor Ekspektasi kinerja terhadap prilaku pengguna layanan SiCantik lebih kecil dari nilai t-tabel $(1,96)$ yaitu 0,471 .

9. Hipotesis kesembilan (H9) yaitu tidak terdapat efek moderasi umur yang memperkuat hubungan antara Ekspektasi usaha terhadap prilaku pengguna layanan SiCantik. Hipotesis ini ditolak karena nilai t-statistics dari variabel moderator umur pada faktor Ekspektasi usaha terhadap prilaku pengguna layanan SiCantik lebih kecil dari nilai t-tabel $(1,96)$ yaitu 0,403 .

10. Hipotesis kesepuluh (H10) yaitu tidak terdapat efek moderasi umur yang memperkuat hubungan antara faktor sosial terhadap prilaku pengguna layanan SiCantik. Hipotesis ini ditolak karena nilai t-statistics dari variabel moderator umur pada faktor sosial terhadap prilaku pengguna layanan SiCantik lebih kecil dari nilai t-tabel $(1,96)$ yaitu 0,369 .

11. Hipotesis kesebelas (H11) yaitu tidak terdapat efek moderasi umur yang memperkuat hubungan antara kondisi yang memfasilitasi terhadap prilaku pengguna layanan SiCantik. Hipotesis ini ditolak karena variabel moderator umur pada faktor kondisi yang memfasilitasi terhadap prilaku pengguna layanan SiCantik lebih kecil dari nilai t-tabel $(1,96)$ yaitu 0,257 .

\section{Pembahasan Hasil Penelitian}

\section{a. Pengaruh Ekspektasi Kinerja terhadap prilaku pengguna layanan SiCantik}

Ekspektasi kinerja mempunyai nilai t-stastistics sebesar 4.464 yang berarti nilai tersebut diatas nilai t-tabel 1,96. Nilai p-values variabel ekspektasi kinerja $(0,001<0,000)$ hasil tersebut menunjukkan bahwa ekspektasi kinerja berpengaruh positif terhadap minat pemanfaatan. 
Besar pengaruh variabel ekspektasi kinerja terhadap prilaku pengguna sesuai nilai original sample yaitu 0,601 sehingga variabel ekspektasi kinerja mempengaruhi variabel minat pemanfaatan sebesar $60.1 \%$. Berdasarkan hasil tersebut penggunaan layanan SiCantik percaya bahwa menggunakan suatu sistem tertentu akan meningkatkan kinerja pekerjaannya.

b. Pengaruh Ekspektasi Usaha terhadap prilaku pengguna layanan SiCantik

Ekspektasi usaha mempunyai nilai t-stastistics sebesar 3.103 yang berarti nilai tersebut diatas nilai t-tabel 1,96 . Nilai p-values variabel ekspektasi kinerja $(0,001<0,004)$ hasil tersebut menunjukkan bahwa ekspektasi kinerja berpengaruh positif terhadap minat pemanfaatan.

Besar pengaruh variabel ekspektasi kinerja terhadap prilaku pengguna sesuai nilai original sample yaitu 0,299 sehingga variabel ekspektasi kinerja mempengaruhi variabel minat pemanfaatan sebesar $29.9 \%$. Berdasarkan hasil tersebut penggunaan layanan SiCantik percaya bahwa Seberapa jauh seseorang percaya bahwa menggunakan sesuatu sistem akan bebas dari usaha.

\section{c. Pengaruh Faktor Sosial terhadap prilaku pengguna layanan SiCantik}

Faktor sosial mempunyai nilai t-stastistics sebesar 2.093 yang berarti nilai tersebut diatas nilai t-tabel 1,96 . Nilai p-values variabel ekspektasi kinerja $(0,001<0,045)$ hasil tersebut menunjukkan bahwa ekspektasi kinerja berpengaruh positif terhadap minat pemanfaatan.

Besar pengaruh variabel ekspektasi kinerja terhadap prilaku pengguna sesuai nilai original sample yaitu 0,297 sehingga variabel ekspektasi kinerja mempengaruhi variabel minat pemanfaatan sebesar $29.7 \%$. Berdasarkan hasil tersebut penggunaan layanan SiCantik percaya bahwa Persepsi seseorang bahwa kebanyakan orang yang penting baginya berfikir bahwa dia seharusnya atau tidak seharusnya melakukan perilaku bersangkutan.

\section{d. Pengaruh kondisi yang memfasilitasi terhadap} prilaku pengguna layanan SiCantik

Kondisi yang memfasilitasi mempunyai nilai tstastistics sebesar 1.426 yang berarti nilai tersebut dibawah nilai t-tabel 1,96. Nilai p-values variabel ekspektasi kinerja $(0,001>0,164)$ hasil tersebut menunjukkan bahwa kondisi tang memfasilitasi tidak berpengaruh positif terhadap minat pemanfaatan.

Berdasarkan hasil tersebut penggunaan layanan SiCantik kurang percaya bahwa Seberapa jauh suatu inovasi dipersepsikan sebagai sesuatu yang konsisten dengan nilai-nilai yang ada, Merefleksikan persepsi-persepsi dari batasan-batasan internal dan eksternal pada perilaku dan meliputi keyakinansendiri, kondisi-kondisi pemfasilitasi teknologi.

\section{e. Variabel Moderator Jenis Kelamin dan Umur Mempengaruhi Ekspektasi Kinerja terhadap layanan SiCantik}

Variabel moderator jenis kelamin dan umur tidak mempengaruhi variabel ekspektasi kinerja terhadap prilaku pengguna layanan SiCantik yang mempunyai nilai t-stastistics variabel moderator jenis kelamin sebesar 0,594 dan variabel moderator umur sebesar 0,471 yang berarti nilai tersebut kurang dari nilai t-tabel 1,96. Nilai p-values variabel moderator jenis kelamin yang mempengaruhi variabel ekspektasi kinerja terhadap prilaku pengguna $(0,557>0,05)$ dan variabel moderator umur yang mempengaruhi variabel ekspektasi kinerja terhadap prilaku pengguna $(0.641>0,05)$ hasil tersebut menunjukkan bahwa tidak terdapat efek moderasi jenis kelamin dan umur yang memperkuat hubungan antara ekspektasi kinerja terhadap prilaku pengguna layanan SiCantik

f. Variabel Moderator Jenis Kelamin dan Umur Mempengaruhi Ekspektasi Usaha terhadap layanan SiCantik

Variabel moderator jenis kelamin dan umur tidak mempengaruhi variabel ekspektasi usaha terhadap prilaku pengguna layanan SiCantik yang mempunyai nilai t-stastistics variabel moderator jenis kelamin sebesar 0,278 dan variabel moderator umur sebesar 0,403 yang berarti nilai tersebut kurang dari nilai t-tabel 1,96. Nilai p-values variabel moderator jenis kelamin yang mempengaruhi variabel ekspektasi kinerja terhadap prilaku pengguna $(0,783>0,05)$ dan variabel moderator umur yang mempengaruhi variabel ekspektasi kinerja terhadap prilaku pengguna $(0.690>0,05)$ hasil tersebut menunjukkan bahwa tidak terdapat efek moderasi jenis kelamin dan umur yang memperkuat hubungan antara ekspektasi kinerja terhadap prilaku pengguna layanan SiCantik

g. Variabel Moderator Jenis Kelamin dan Umur Mempengaruhi faktor sosial terhadap layanan SiCantik

Variabel moderator jenis kelamin dan umur tidak mempengaruhi variabel faktor sosial terhadap prilaku pengguna layanan SiCantik yang mempunyai nilai t-stastistics variabel moderator jenis kelamin sebesar 0,237 dan variabel moderator umur sebesar 0,369 yang berarti nilai tersebut kurang dari nilai t-tabel 1,96. Nilai p-values variabel moderator jenis kelamin yang mempengaruhi variabel ekspektasi kinerja terhadap prilaku pengguna $(0,815>0,05)$ dan variabel moderator umur yang mempengaruhi variabel ekspektasi kinerja terhadap prilaku pengguna $(0.715>0,05)$ hasil tersebut menunjukkan bahwa tidak terdapat efek moderasi jenis kelamin dan umur yang memperkuat hubungan antara ekspektasi kinerja terhadap prilaku pengguna layanan SiCantik

h. Variabel Moderator Umur Mempengaruhi kondisi yang memfasilitasi terhadap layanan SiCantik

Variabel moderator umur tidak mempengaruhi variabel kondisi yang memfasilitasi terhadap prilaku pengguna layanan SiCantik yang mempunyai nilai t-stastistics variabel moderator 
umur sebesar 0,257 yang berarti nilai tersebut kurang dari nilai t-tabel 1,96. Nilai p-values variabel moderator umur yang mempengaruhi variabel kondisi yang memfasilitasi terhadap prilaku pengguna $(0.799>0,05)$ hasil tersebut menunjukkan bahwa tidak terdapat efek moderasi umur yang memperkuat hubungan antara kondisi yang memfasilitasi terhadap prilaku pengguna layanan SiCantik

\section{SIMPULAN}

Berdasarkan hasil analisis dan pembahasan maka dapat disimpulkan penilitian sebagai berikut :

1. Ekspektasi kinerja berpengaruh positif terhadap prilaku pengguna layanan SiCantik sebesar 60.1\%. Pengguna percaya bahwa menggunakan layanan SiCantik dapat meningkatkan kinerja pekerjaannya. Kemudian, pengguna juga percaya bahwa menggunakan layanan Sicantik akan berguna untuk memberikan informasi proses perijinan yang diajukan, dan pengguna beranggapan bekerja dengan layanan SiCantik meningkatkan kemampuan dalam bidang teknologi. Ekspektasi usaha berpengaruh positif terhadap prilaku pengguna layanan SiCcantik sebesar $29.9 \%$. Pengguna merasa layanan SiCantik sangat mudah digunakan dalam pekerjaan. Layanan SiCantik merupakan sistem yang mudah diakses dengan cepat dalam melakukan pekerjaan dan pengguna tidak membutuhkan watktu yang lama untuk menggunakan layanan SiCantik. Faktor sosial berpengaruh positif terhadap prilaku pengguna layanan SiCcantik sebesar 29.7\%. Pengguna merasa layanan SiCantik ini perlu disebarkan atau diberitahukan kepada orang lain karena pengguna merasa dengan adanya layanan SiCantik akan lebih memudahkan dalam proses permohonan perijinan. Sedangkan untuk pengaruh kondisi yang memfasilitasi tidak berpengaruh kepada prilaku pengguna layanan SiCantik. Hal ini disebabkan karena sejauh mana seseorang percaya bahwa infrastruktur organisasional dan teknikal tersedia untuk mendukung system.

2. Variabel moderator jenis kelamin dan umur tidak memperkuat hubungan antara ekspektasi kinerja dengan prilaku pengguna layanan SiCantik, ekspektasi usaha dengan prilaku pengguna layanan SiCantik, faktor sosial dengan prilaku pengguna layanan SiCantik, dan kondisi yang memfasilitasi dengan prilaku pengguna layanan SiCantik

\section{REFERENSI}

[1] I. I. Dewa, G. P. Widnyana, and I. K. Yadnyana, "Implikasi Model Utaut Dalam Menjelaskan Faktor Niat Dan Penggunaan Sipkd Kabupaten Tabanan," J. Akunt. Univ. Udayana, vol. 112, pp. 2302-8556, 2015.

[2] M. B. Rivai, "Penerapan Model The Unified Theory of Acceptance and Use of Technology (UTAUT) untuk Memahami Tingkat Penerimaan dan Penggunaan Elearning (Be smart)," Skripsi, pp. 58-62, 2014.
[3] Bernoulli, "Pengaruh Teknologi Adopsi Koran Digital (E-Paper) Terhadap Perilaku Penggunaan Dengan Pendekatan UTAUT (Studi pada Harian Umum Pikiran Rakyat) Mohammed Bernoulli," vol. 2, no. 3, pp. 26812690, 2015.

[4] W. Abdillah, Metode Penelitian Terpadu Sistem Informasi. indonesia: ANDI, 2018.

[5] E. FIRDAUS, “ANALISIS PERILAKU PENGGUNA SISTEM 'UNIKOM KULIAH ONLINE' MENGGUNAKAN MODEL UTAUT," vol. 14, no. 2, pp. 297-310, 2004.

[6] D. Y. Prasetyo, "Penerapan Metode Utaut (Unified Theory of Acceptance and Use of Technology) Dalam Memahami Penerimaan Dan Penggunaan Website Kkn Lppm Unisi," Sistemasi, vol. 6, no. 2, pp. 26-34, 2017.

[7] T. W. Puteri Vania Shara, "PENERAPAN MODEL UNIFIED THEORY OF ACCEPTANCE AND USE OF TECHNOLOGY (UTAUT) UNTUK MENGANALISIS MINAT PENGGUNA SMARTPHONE DI KOTA BANDUNG," E-Jurnal Akunt. Univ. Udayana, pp. 1270-1297, 2016.

[8] Melyani, “ANALISIS FAKTOR-FAKTOR YANG MEMPENGARUHI KEPUTUSAN PENGGUNAAN KONSUMEN E-COMMERCE ZOYA MENGGUNAKAN MODEL UAUT ( UNIFIED THEORY ACCEPTANCE AND USE TECHNOLOGY ) - STUDY," no. 2016, pp. 639-645, 2018.

[9] K. Muhammad Nasir1, "KAJIAN MENGENAI PENGGUNAAN E-LEARNING DI KALANGAN MAHASISWA PERGURUAN TINGGI SWASTA DI KOTA PALEMBANG,” pp. 77-86.

[10] H. Sulistyowati, “Analisis Penerimaan dan Penggunaan Pengguna Terhadap Penerapan Sistem E-office di Universitas Airlangga dengan Menggunakan Model," 2013.

[11] M. Indriani, "EFEK MODERASI DARI USIA DAN JENIS KELAMIN DALAM PENERIMAAN E-KTP THE MODERATING EFFECTS OF AGE AND GENDER ON THE ACCEPTANCE OF INDONESIAN SMART IDENTITY CARD," vol. 14, no. 1, pp. 43-62, 2012.

[12] G. A. M. M. Marhaeni, "MENGGUNAKAN MODEL UNIFIED THEORY OF ACCEPTANCE AND USE OF," vol. 1, no. 3, pp. 42-56, 2014.

[13] E. Silviasasmi, "PROPOSAL SKRIPSI ANALISIS PERILAKU PENGGUNA GARDA SUMBER PEMBELAJARAN TERBUKA INDONESIA ( GARSUPATI ) MENGGUNAKAN MODEL UNIFIED THEORY OF ACCEPTANCE AND USE OF TECHNOLOGY ( UTAUT ) Oleh Ella Silviasasmi JURUSAN PENDIDIKAN TEKNIK INFORMATIKA," 2017.

[14] agustini ketut sugihartini nyoman, Cara Cepat 
ISSN 2252-9063

Kumpulan Artikel Mahasiswa Pendidikan Teknik Informatika

(KARMAPATI)

KดRMดคดTI

Volume 8, Nomor 2, Tahun 2019

Mengembangkan Istrumen dan Teknik Analisisnya, 1st ed. PT RajaGrafindo Persada, depok, 2018. 